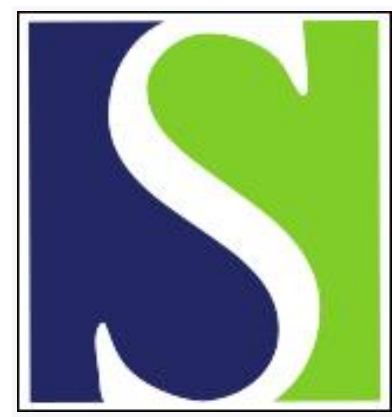

Scand J Work Environ Health 2018;44(4):423-431

https://doi.org/10.5271/sjweh.3721

Published online: 19 Feb 2018, Issue date: 01 Jul 2018

DNA damage and genomic instability among workers formerly and currently exposed to asbestos

by Milić M, Neri M, Ceppi M, Bruzzone M, Munnia A, Ugolini D, Cristaudo A, Bonotti A, Peluso ME, Bonassi S

Surveillance programs of cohorts with past exposure to asbestos lack validated tools for the early identification of subgroups and/or individuals with the highest risk of cancer. Our results show a significant increase of genomic instability in these workers, paving the way for the possible inclusion of the micronuclei (buccal micronucleus) cytome assay in surveillance programs of subjects with past exposure to carcinogens.

Affiliation: Department of Human Sciences and Quality of Life Promotion, San Raffaele University, Rome, Italy. stefano.bonassi@sanraffaele.it

Key terms: asbestos; biomarker; buccal mucosa; DNA; DNA damage; genomic instability; micronucleus cytome assay; mutagenicity test; occupational exposure

This article in PubMed: www.ncbi.nlm.nih.gov/pubmed/29457967

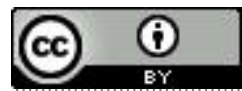




\title{
DNA damage and genomic instability among workers formerly and currently exposed to asbestos
}

\author{
by Mirta Milić, PhD, ${ }^{1}$ Monica Neri, PhD, ${ }^{2}$ Marcello Ceppi, MSc, ${ }^{3}$ Marco Bruzzone, MSc, ${ }^{3}$ Armelle Munnia, $P h D,{ }^{4}$ Donatella \\ Ugolini, MSc, ${ }^{3,5}$ Alfonso Cristaudo, MD, ${ }^{6}$ Alessandra Bonotti, PhD, ${ }^{6}$ Marco E Peluso, PhD, ${ }^{4}$ Stefano Bonassi, PhD ${ }^{2,7}$
}

\begin{abstract}
Milić M, Neri M, Ceppi M, Bruzzone M, Munnia A, Ugolini D, Cristaudo A, Novatti A, Peluso ME, Bonassi S. DNA damage and genomic instability among workers formerly and currently exposed to asbestos. Scand J Work Environ Health. 2018;44(4):423-431. doi:10.5271/sjweh.3721
\end{abstract}

Objectives Despite an asbestos ban in the European Union, exposure to asbestos still represents an occupational risk. Biomarkers of DNA damage and genomic instability in groups exposed to asbestos may contribute to the identification of subgroups/subjects at higher risk.

Methods A cross-sectional study was conducted on 468 male individuals ( 80 working in occupational settings with potential exposure to asbestos fibers, 202 retired workers with past exposure, and 186 non-exposed controls) to compare genomic instability, cell proliferation and differentiation level using the non-invasive micronucleus buccal cytome assay. Data on demographic variables, lifestyle, and occupational history were collected with a standardized questionnaire. Micronuclei $(\mathrm{MN})$ and other biomarkers of DNA damage and genomic instability were scored in a minimum of 2000/1000 cells per individual, respectively.

Results Univariate and multivariate analysis showed opposite associations of MN frequency with current and former exposure. Compared to unexposed controls, workers with current potential exposure to asbestos had $55 \%$ lower MN frequency [ $95 \%$ confidence interval (CI) $71-29 \%, \mathrm{P}<0.001]$ while those with past exposure had $34 \%$ higher MN frequency $(95 \%$ CI $1-77 \%, \mathrm{P}<0.001)$. The frequency of cells with condensed chromatin and binucleated cells was elevated among formerly exposed workers. The multivariate analysis did not reveal any actual confounders, although lower MN frequency was observed among subjects eating fresh fruit or vegetables every day or taking vitamin supplements.

Conclusions Active workers with potential exposure to asbestos fibers did not show increased genomic damage. On the contrary, workers exposed in the past experienced a persistently elevated genomic instability, which may be used for risk assessment at subgroup or individual level.

Key terms biomarker; buccal mucosa; micronucleus cytome assay; mutagenicity test; occupational exposure.

Occupational exposure to asbestos fibers is still present in the European Union (EU) despite a ban since 1 January 2005 (1). Workers exposed in the past are also at risk due to long latency of asbestos-related diseases (2). Italy had been the second asbestos producer in Europe after the Soviet Union, with a per capita share of about $1 \mathrm{~kg}$ per year, until a national ban in $1992(3,4)$. Due to this reason, a surveillance program has been implemented, the so called ReNaM (Registro Nazionale Mesoteliomi), which oversees prevention and control activities concerning asbestos-related diseases (4). According to ReNaM reports, $69 \%$ of total cases of malignant mesothelioma (MM) can be attributed to occupational exposure to asbestos (OEA), with a remarkable gender-

\footnotetext{
1 Mutagenesis Unit, Institute for Medical Research and Occupational Health, Zagreb, Croatia.

2 Unit of Clinical and Molecular Epidemiology, IRCCS San Raffaele Pisana, Rome, Italy.

3 Unit of Clinical Epidemiology, Ospedale Policlinico San Martino, Genoa, Italy.

4 Cancer Risk Factor Branch, Cancer Prevention Laboratory, ISPO-Cancer Prevention and Research Institute, Florence, Italy.

5 Department of Internal Medicine, University of Genoa, Genoa, Italy.

6 Department of Translational Research and New Technologies in Medicine and Surgery, University of Pisa, Pisa, Italy.

7 Department of Human Sciences and Quality of Life Promotion, San Raffaele University, Rome, Italy.
}

Correspondence to: Stefano Bonassi, PhD, Department of Human Sciences and Quality of Life Promotion, San Raffaele University, Rome, Italy [E-mail: stefano.bonassi@sanraffaele.it] 
related disparity (men $81 \%$ and women 33\%) (5). The same reports recognized the presence of OEA in 38 economic sectors (eg, shipbuilding and repair, railway carriages maintenance, oil refinery) and included a geographical map of incidence rates.

Asbestos fibers are not mutagenic per se, but their persistence in the lung is a continuous source of reactive nitrogen and oxygen species (ROS) and inflammation, which may influence gene transcription and expression, affect signaling pathways, increase replication errors and genomic instability. The presence of these alterations may lead to cancer and other diseases, offering at the same time a valuable opportunity for studying early events associated with OEA (6-9). Asbestos fibers interfere with the mitotic process causing the formation of aneuploid cells and cells with abnormal number of centrosomes (10). The continuous ROS production in the lung may induce micronuclei $(\mathrm{MN})(11,12)$, and the mislocalization of the cytokinetic protein aurora $\mathrm{B}$ and of other proteins (13).

The formation of $\mathrm{MN}$ can be induced by clastogens or by aneugens events (14), including the alteration of genes controlling the spindle apparatus or the cell cycle, tubulin defects, epigenetic modifications of histones/centromeric DNA. All these events may eventually lead to aneuploidy and creation of polyploidic cells (14). Therefore, measuring the MN frequency in peripheral blood lymphocytes may specifically reveal current or former OEA, together with subjects at increased risk of cancer.

The usual route of OEA is inhalation, which makes epithelial cells of inner airways pathway the first to be exposed. The presence of genetic damage in these cells, measured with the buccal micronucleus cytome assay (BMCyt) is a suitable and reliable OEA biomarker (15), while the extent of DNA damage is clearly linked to long-term cancer risk $(16,17)$.

The aim of this study was to compare the levels of genomic instability, cell proliferation and differentiation - as measured by BMCyt - in three groups of subjects with different histories of OEA, namely, active workers with potentially OEA, retired workers exposed in the past, and unexposed controls. All groups were selected from areas considered at high risk of asbestos-related diseases, as demonstrated by incidence rates of MM, ranging in these areas from 4.7-13.7 per 100000 (18).

The validation of this approach in groups of subjects currently/ formerly exposed to carcinogens like asbestos may have a major impact on public health, providing a critical and reliable tool for the identification of subgroups of exposed subjects at higher risk of cancer and other asbestos-related diseases and in the medical surveillance of cohorts of workers with past exposure to carcinogens.

\section{Methods}

\section{Study population}

After obtaining approval from the Ethics Committee of the coordinating center in Rome, volunteers were recruited from two areas with a high concentration of shipbuilding and construction industries (the provinces of Pisa and Genoa). The study was performed on 468 male individuals: (i) 80 of whom, mostly working in construction industry and included in the occupational surveillance program of the University Hospital of Pisa, were classified as currently exposed; (ii) 202 were selected from a cohort of former workers with known past OEA, followed up in the framework of a surveillance program at the University Hospital of Pisa; and (iii) 186 unexposed controls were selected at the Ospedale Policlinico San Martino of Genoa among blood donors without history of occupational or environmental OEA. All currently and formerly exposed workers, received a medical check-up and follow-up routinely provided to workers in the surveillance program including spirometry, radio-thoracic X-ray or low-dose chest tomography. All participants provided their written consent before interview and sample collection. Trained personnel administered a standardized questionnaire in order to collect detailed information on demographic variables, lifestyle, diet and occupational history (including job title, tasks, duration and period), personal and family history of chronic diseases (especially focusing on cancer of the respiratory tract). Duration of employment(s) entailing OEA was used as a proxy for exposure duration. Controls were selected among same age range subjects as exposed individuals and after reviewing their answers to the questionnaire and their occupational history. We included only males as a consequence of the gender difference in access to occupations in shipbuilding and construction industries.

\section{Buccal cell collection}

Subjects rinsed their mouth three times with tap water. Buccal cells samples were collected from both cheeks using a toothbrush according to a standardized protocol (19), placed into $30 \mathrm{ml}$ Saccomanno's fixative (Histoline laboratories, Milano, Italy), blindly coded and kept at $4{ }^{\circ} \mathrm{C}$ for maximum one month and transported under $4^{\circ} \mathrm{C}$ to the lab for final processing and scoring. To avoid intra-laboratory heterogeneity, a single experienced scorer was in charge of scoring.

\section{Buccal cell preparation and staining}

Samples were processed and stained according to the protocol described by Thomas et al (19). Slides were 
covered with coverslips and kept in the dark at $-20^{\circ} \mathrm{C}$ until microscope examination.

\section{Scoring}

Slides were scored blindly using transmitted light microscopy under far red fluorescence at $1000 \times$. A minimum of 1000 cells was counted in order to determine the frequency of each cell type in the sample, using scoring criteria previously described $(19,20)$. Nuclear changes were classified according to HUMNxl criteria as: normal basal cells, normal differentiated cells, binucleated cells, cells with condensed chromatin (CC), pyknotic cells, cells with karyorrhectic chromatin, and karyolitic cells. DNA damage biomarkers (cells with MN and nuclear buds, including the so-called "broken eggs") were scored in a minimum of 2000 differentiated cells.

\section{Statistical analysis}

Statistics of the main predictors were computed for controls and exposed subjects. Mean and standard deviation (SD) of continuous variables were estimated and compared according to the levels of exposure using the ANOVA model. Any difference in the frequency of categorical variables through the exposure categories was checked by applying the Fisher's exact test.

In the univariate setting, due to the discrete nature of indexes provided by the buccal micronucleus assay, non parametric Kruskal-Wallis test was applied to identify biomarkers that were differentially distributed between the exposure groups.

Several demographic and exposure variables have been linked to MN frequency, such as age, gender, smoking, alcohol consumption, dietary habit, exposure to chemical carcinogens and radiation (19-22). Therefore, inferential analysis was performed by means of regression models to take into account the possible confounding effect due to the main predictors considered. Models were fitted to the data assuming that MN count follows the negative binomial distribution (23). This distribution provides efficient estimates of the standard errors of the model parameters in presence of over dispersion, a phenomenon that frequently occurs with count data. In fact when this parameter tends to zero, negative binomial distribution reduces to the Poisson distribution (24). The model estimates the ratio between the mean value of $\mathrm{MN}$ in the exposed groups with respect to the mean value in controls, adjusted by the concomitant effect of the main predictors. Log-likelihood ratio test (LRT) was performed to test the contribution of each predictor to the statistical model. $\mathrm{P}<0.05$ was considered as the threshold for significant results. All statistical analyses were performed using STATA statistical software, release 14 (StataCorp, College Station, TX, USA).

\section{Results}

A descriptive analysis of the main characteristics of the three study groups is reported in table 1. Significant differences were found by age, since subjects with current OEA were younger (mean 46.29 years versus 54.47 for controls, and 61.66 for formerly exposed subjects, respectively). Similarly, an unbalanced distribution of smoking habit was observed: the proportion of never smokers was higher among the unexposed controls (43.5\%), formerly exposed workers had the highest proportion of former smokers (57.4\%), while currently exposed subjects were those with the highest proportion of current smokers, ie, $43.8 \%$, more than double the other groups. Exposure to passive smoking at home was similar in the three groups, while exposure at work was more frequent in the formerly exposed, probably due to relatively recent regulatory changes.

The presence of working-related respiratory diseases was almost entirely restricted to the group of workers with former OEA ( $7 / 7$ cases of silicosis and 20/21 cases of asbestosis). The list of other respiratory diseases included mostly asthma, chronic obstructive pulmonary disease, bronchitis, pneumonia and emphysema.

Diet profiling revealed significantly different patterns, with currently exposed workers eating fresh fruit, fresh vegetable, and cooked vegetables less frequently than the other groups. No major differences were found regarding vitamin supplementation and alcohol drinking.

The univariate analysis comparing the frequency of all endpoints measured with the BMCyt in the three study groups is reported in table 2. Basal, CC, binucleated, and $\mathrm{MN}$ cells showed a differential distribution between the three exposure groups. Basal cells were less common among the formerly exposed subjects when compared to the unexposed controls, and even rarer among the currently exposed. $\mathrm{CC}$ and binucleated cell frequencies were higher in the formerly exposed compared to other groups. The MN cell frequency was higher among the formerly exposed subjects and lower among the currently exposed workers (both statistically significant), when compared to the group of unexposed subjects.

Results of the negative binomial distribution regression model are shown in table 3 . Frequency ratios adjusted for actual and potential confounders (age, smoking habit, passive smoking, history of respiratory diseases) essentially confirmed results from the univariate analysis.

Biomarkers investigated in this analysis which showed a statistically significant association with OEA were basal cells, MN and broken eggs. Although LRT is not significant, it should be observed that in formerly exposed subjects, binucealated cell frequency was $60 \%$ 
Table 1. Main characteristics of the three study groups, unexposed and exposed to asbestos. [SD=standard deviation.]

\begin{tabular}{|c|c|c|c|c|c|c|c|c|c|c|c|c|c|c|c|c|c|}
\hline \multirow[t]{2}{*}{ Variable } & \multicolumn{4}{|c|}{ Total } & \multicolumn{4}{|c|}{ Unexposed } & \multicolumn{4}{|c|}{ Currently exposed } & \multicolumn{4}{|c|}{ Formerly exposed } & \multirow[t]{2}{*}{ P-value } \\
\hline & $\mathrm{N}$ & $\%$ & Mean & SD & $\mathrm{N}$ & $\%$ & Mean & SD & $\mathrm{N}$ & $\%$ & Mean & SD & $\mathrm{N}$ & $\%$ & Mean & SD & \\
\hline Age & 468 & & 56.18 & 8.90 & 186 & & 54.47 & 5.68 & 80 & & 46.29 & 8.64 & 202 & & 61.66 & 7.30 & $<0.001$ \\
\hline Body mass index & 460 & & 26.77 & 3.36 & 186 & & 26.50 & 3.20 & 73 & & 26.70 & 3.15 & 201 & & 27.04 & 3.55 & 0.282 \\
\hline \multicolumn{18}{|l|}{ Smoking } \\
\hline Never & 163 & 34.8 & & & 81 & 43.5 & & & 26 & 32.5 & & & 56 & 27.7 & & & $<0.001$ \\
\hline Former & 204 & 43.6 & & & 69 & 37.1 & & & 19 & 23.7 & & & 116 & 57.4 & & & \\
\hline Current & 101 & 21.6 & & & 36 & 19.4 & & & 35 & 43.8 & & & 30 & 14.9 & & & \\
\hline Duration-years & 305 & & 25.84 & 13.1 & 105 & & 25.87 & 12.70 & 54 & & 22.04 & 11.18 & 146 & & 27.22 & 13.87 & 0.046 \\
\hline Pack-years & 299 & & 22.42 & 18.2 & 103 & & 20.36 & 15.96 & 54 & & 20.67 & 16.63 & 142 & & 24.58 & 20.09 & 0.149 \\
\hline \multicolumn{18}{|l|}{ Passive smoking } \\
\hline At home & 252 & 53.8 & & & 100 & 53.8 & & & 40 & 50.0 & & & 112 & 55.4 & & & 0.710 \\
\hline At work & 236 & 50.4 & & & 70 & 37.6 & & & 22 & 27.5 & & & 144 & 71.3 & & & $<0.001$ \\
\hline Both & 141 & 30.1 & & & 43 & 23.1 & & & 12 & 15.0 & & & 86 & 42.6 & & & $<0.001$ \\
\hline \multicolumn{18}{|c|}{ Respiratory diseases } \\
\hline Silicosis & 7 & 1.5 & & & 0 & 0 & & & 0 & 0 & & & 7 & 3.5 & & & 0.010 \\
\hline Asbestosis & 21 & 4.5 & & & 0 & 0 & & & 1 & 1.2 & & & 20 & 9.9 & & & $<0.001$ \\
\hline Other $^{b}$ & 109 & 23.3 & & & 21 & 11.3 & & & 6 & 7.5 & & & 82 & 40.6 & & & $<0.001$ \\
\hline \multicolumn{18}{|c|}{ Vitamin supplement } \\
\hline No & 420 & 89.7 & & & 163 & 87.6 & & & 70 & 87.5 & & & 187 & 92.6 & & & 0.254 \\
\hline Yes & 46 & 9.8 & & & 23 & 12.4 & & & 8 & 10.0 & & & 15 & 7.4 & & & \\
\hline \multicolumn{18}{|c|}{ Alcohol consumption } \\
\hline Wine & 410 & 87.6 & & & 166 & 89.3 & & & 66 & 82.5 & & & 178 & 88.2 & & & 0.269 \\
\hline Beer & 306 & 65.3 & & & 135 & 72.6 & & & 55 & 68.7 & & & 116 & 57.4 & & & 0.013 \\
\hline Spirits & 47 & 10.0 & & & 17 & 9.1 & & & 4 & 5.0 & & & 26 & 12.9 & & & 0.278 \\
\hline \multicolumn{18}{|l|}{ Fresh fruit } \\
\hline$\geq 1 /$ day & 380 & 81.1 & & & 154 & 82.8 & & & 57 & 71.2 & & & 169 & 83.7 & & & 0.041 \\
\hline$\geq 1 /$ month & 55 & 11.8 & & & 16 & 8.6 & & & 15 & 18.7 & & & 24 & 11.9 & & & \\
\hline <monthly & 24 & 5.1 & & & 14 & 7.5 & & & 4 & 5.0 & & & 6 & 3.0 & & & \\
\hline \multicolumn{18}{|l|}{ Fresh vegetables } \\
\hline$\geq 1 /$ day & 311 & 66.5 & & & 142 & 76.3 & & & 43 & 53.7 & & & 126 & 62.4 & & & 0.005 \\
\hline$\geq 1 /$ month & 119 & 25.4 & & & 32 & 17.2 & & & 27 & 33.7 & & & 60 & 29.7 & & & \\
\hline$<$ monthly & 33 & 7.1 & & & 12 & 6.5 & & & 7 & 8.8 & & & 14 & 6.9 & & & \\
\hline \multicolumn{18}{|l|}{ Cooked vegetables } \\
\hline$\geq 1 /$ day & 175 & 37.3 & & & 83 & 44.6 & & & 21 & 26.2 & & & 71 & 35.1 & & & 0.001 \\
\hline$\geq 1 /$ month & 178 & 38.0 & & & 61 & 32.8 & & & 26 & 32.5 & & & 91 & 45.0 & & & \\
\hline$<$ monthly & 100 & 21.4 & & & 40 & 21.5 & & & 28 & 35.0 & & & 32 & 15.8 & & & \\
\hline
\end{tabular}

a P-values are calculated with the $\chi^{2} / \mathrm{ANOVA}$ test for categorical/continuous variables.

${ }^{\mathrm{b}}$ Mostly asthma, chronic obstructive pulmonary disease, bronchitis, pneumonia and emphysema.

Table 2. Comparison of the main endpoints of the buccal micronucleus cytome assay in the three study groups (frequency per 1000 cells). [SD=standard deviation.]

\begin{tabular}{|c|c|c|c|c|c|c|c|c|c|}
\hline \multirow[t]{2}{*}{ Variable } & \multicolumn{2}{|c|}{$\begin{array}{c}\text { Total } \\
(\mathrm{N}=486)\end{array}$} & \multicolumn{2}{|c|}{$\begin{array}{c}\text { Unexposed } \\
(\mathrm{N}=186)\end{array}$} & \multicolumn{2}{|c|}{$\begin{array}{l}\text { Currently exposed } \\
\qquad(\mathrm{N}=80)\end{array}$} & \multicolumn{2}{|c|}{$\begin{array}{l}\text { Formerly exposed } \\
\qquad(\mathrm{N}=202)\end{array}$} & \multirow{2}{*}{$\begin{array}{r}\text { P-value } \\
\text { (Kruskal } \\
\text { Wallis) }\end{array}$} \\
\hline & Mean & SD & Mean & SD & Mean & SD & Mean & SD & \\
\hline Basal cells & 19.22 & 63.58 & 28.97 & 82.14 & 7.01 & 32.91 & 15.08 & 50.92 & $<0.001$ \\
\hline Differentiated cells & 414.73 & 245.83 & 403.13 & 258.59 & 367.94 & 247.82 & 443.93 & 229.95 & 0.058 \\
\hline Binucleated cells & 10.53 & 13.39 & 8.12 & 13.25 & 9.68 & 10.30 & 13.08 & 14.18 & $<0.001$ \\
\hline $\begin{array}{l}\text { Cells with condensed } \\
\text { chromatin }\end{array}$ & 115.66 & 83.10 & 101.18 & 78.32 & 110.54 & 82.90 & 131.02 & 85.18 & 0.001 \\
\hline Pycnotic cells & 5.22 & 6.92 & 4.90 & 6.85 & 6.88 & 7.41 & 4.86 & 6.72 & 0.187 \\
\hline Karyorrhectic cells & 52.88 & 70.03 & 57.50 & 78.51 & 47.93 & 56.19 & 50.58 & 66.66 & 0.787 \\
\hline Karyolitic cells & 257.78 & 185.75 & 261.93 & 203.96 & 224.04 & 174.20 & 267.33 & 171.42 & 0.246 \\
\hline Micronucleia & 0.89 & 1.21 & 0.86 & 1.15 & 0.39 & 0.53 & 1.10 & 1.38 & $<0.001$ \\
\hline Nuclear budsa & 0.06 & 0.20 & 0.08 & 0.26 & 0.04 & 0.16 & 0.03 & 0.11 & 0.189 \\
\hline Broken eggs ${ }^{a}$ & 0.10 & 0.30 & 0.14 & 0.38 & 0.08 & 0.24 & 0.05 & 0.17 & 0.137 \\
\hline
\end{tabular}

a Frequency per 1000 differentiated mononuclear cells. 
Table 3. Results of negative binomial regression analysis comparing asbestos exposure groups by the main endpoints of the buccal micronucleus cytome assay (frequency per 1000 cells). All models were adjusted for age, smoking habit, passive smoking, history of respiratory diseases. [Cl=confidence interval; LRT=log likelihood ratio test]

\begin{tabular}{|c|c|c|c|c|}
\hline Biomarker & Exposure & $\begin{array}{l}\text { Frequency } \\
\text { Ratio }\end{array}$ & $95 \% \mathrm{Cl}$ & $\begin{array}{l}\text { P-value } \\
\text { LRT }\end{array}$ \\
\hline \multirow[t]{3}{*}{ Basal cells } & Unexposed & Ref. & & 0.027 \\
\hline & Currently exposed & 0.21 & $0.07-0.63$ & \\
\hline & Formerly exposed & 0.61 & $0.26-1.42$ & \\
\hline \multirow{3}{*}{$\begin{array}{l}\text { Differentiated } \\
\text { cells }\end{array}$} & Unexposed & Ref. & & 0.892 \\
\hline & Currently exposed & 0.98 & $0.68-1.40$ & \\
\hline & Formerly exposed & 1.06 & $0.80-1.41$ & \\
\hline \multirow[t]{3}{*}{ Binucleated cells } & Unexposed & Ref. & & 0.106 \\
\hline & Currently exposed & 1.33 & $0.76-2.31$ & \\
\hline & Formerly exposed & 1.62 & $1.02-2.55$ & \\
\hline \multirow{3}{*}{$\begin{array}{l}\text { Cells with con- } \\
\text { densed chromatin }\end{array}$} & Unexposed & Ref. & & 0.101 \\
\hline & Currently exposed & 1.01 & $0.73-1.40$ & \\
\hline & Formerly exposed & 1.33 & $1.02-1.73$ & \\
\hline \multirow[t]{3}{*}{ Pyknotic cells } & Unexposed & Ref. & & 0.124 \\
\hline & Currently exposed & 1.41 & $0.99-2.00$ & \\
\hline & Formerly exposed & 0.95 & $0.71-1.25$ & \\
\hline \multirow{3}{*}{$\begin{array}{l}\text { Karyorrhectic } \\
\text { cells }\end{array}$} & Unexposed & Ref. & & 0.368 \\
\hline & Currently exposed & 0.76 & $0.52-1.11$ & \\
\hline & Formerly exposed & 0.99 & $0.72-1.37$ & \\
\hline \multirow[t]{3}{*}{ Karyolytic cells } & Unexposed & Ref. & & 0.725 \\
\hline & Currently exposed & 0.89 & $0.62-1.26$ & \\
\hline & Formerly exposed & 0.93 & $0.70-1.22$ & \\
\hline \multirow[t]{3}{*}{ Micronucleia } & Unexposed & Ref. & & $<0.001$ \\
\hline & Currently exposed & 0.45 & $0.29-0.71$ & \\
\hline & Formerly exposed & 1.34 & $1.01-1.77$ & \\
\hline \multirow[t]{3}{*}{ Nuclear budsa } & Unexposed & Ref. & & 0.100 \\
\hline & Currently exposed & 0.25 & $0.05-1.20$ & \\
\hline & Formerly exposed & 0.59 & $0.22-1.59$ & \\
\hline \multirow[t]{3}{*}{ Broken eggs ${ }^{a}$} & Unexposed & Ref. & & 0.029 \\
\hline & Currently exposed & 0.28 & $0.09-0.88$ & \\
\hline & Formerly exposed & 0.61 & $0.29-1.26$ & \\
\hline
\end{tabular}

${ }^{a}$ Frequency per 1000 differentiated mononuclear cells.

higher compared to unexposed, while CC cells were one third more frequent. Multivariate analysis of MN frequency confirmed the opposite associations with current and former exposure. Individuals currently exposed to asbestos had a $55 \%$ lower MN frequency $(95 \% \mathrm{CI}$ $71-29 \%$ ), while previously exposed subjects had a $34 \%$ higher frequency (95\% CI 1-77\%), with respect to controls. Currently exposed workers also showed a lower basal cell frequency ratio $(0.21,95 \%$ CI $0.07-0.63)$. A sensitivity analysis was performed to further investigate the effect of the younger age of this group compared to controls (46.3 versus 54.5 years.). Even after matching currently exposed workers with controls by triennial age-class, the results of the analysis confirmed that lower MN frequency among active workers was not due to a confounding effect of age.

Analyses testing a possible effect modification of selected covariates (age and smoking) on the association between exposure and MN frequency did not reveal biologically or statistically relevant findings.

Results concerning a possible association of the endpoints indicating chromosomal instability or DNA
Table 4. Results of negative binomial analysis comparing asbestos exposure groups by frequency of micronuclei, stratified on duration of exposure. All models were adjusted for age, smoking habit, passive smoking, history of respiratory diseases $[\mathrm{Cl}=$ confidence interval; LRT=log likelihood ratio test.]

\begin{tabular}{lccc}
\hline $\begin{array}{l}\text { Micronuclei } \\
\text { exposure }\end{array}$ & Frequency ratio & $95 \% \mathrm{Cl}$ & P-value LRT \\
\hline $\begin{array}{l}\text { Unexposed } \\
\text { Currently exposed }\end{array}$ & Ref. & & $<0.001$ \\
$\quad \leq 12$ years & 0.37 & $0.19-0.74$ & \\
$>12$ years & 0.55 & $0.32-0.93$ & \\
Formerly exposed & & & \\
$\leq 12$ years & 1.44 & $1.07-1.95$ & \\
$>12$ years & 1.13 & $0.78-1.62$ & \\
\hline
\end{tabular}

damage with the OEA duration are shown in table 4 . This analysis confirms the heterogeneity of the genomic damage in currently and formerly exposed workers (LRT $\mathrm{P}<0.001$ ) while it did not show any evidence of association with the duration of exposure.

The multivariate analysis of dietary items, vitamin supplementation, smoking habit, alcohol consumption and other potential confounders did not reveal any statistically significant association, although lower MN frequencies were observed in subjects eating fresh fruits or vegetables every day, or taking vitamin supplements (data not shown).

\section{Discussion}

In this study we evaluated whether the use of the BMCyt in subjects with OEA could be a helpful non-invasive biomarker to assess early changes in the cell and to measure genome stability. The main results clearly show that past OEA, even many years after exposure has ceased, is still associated with DNA damage and genomic instability, conditions that may predict an elevated risk of cancer.

To the best of our knowledge, this is the first study comparing populations exposed in current occupational settings and the pre-asbestos ban conditions. In addition, we have been the first to utilize the BMCyt in human OEA populations (12).

The use of BMCyt has a number of practical advantages when compared to lymphocyte micronucleus assay. First of all, the sampling process is easy and non-invasive, and the exfoliated cells can be preserved for long time at room temperature. Furthermore, the availability of different biomarkers measuring epithelial cells kinetics in the buccal mucosa is critical for a deeper insight into the mechanistic rationale and for a better interpretation of the results (19). Buccal cells have limited DNA repair capacity relative to peripheral blood lymphocytes 
because DNA damage formed in the mitotic basal layer of the epithelial tissue cannot be repaired in the process of differentiation, providing a more reliable measure of genomic instability events in the epithelial respiratory tract (21). After radiation challenge, it has been demonstrated that basal DNA damage can be $83 \%$ higher in buccal cells than lymphocytes (25).

In our study, workers with a past OEA history showed a significantly higher MN frequency when compared to unexposed controls. Results concerning MN are of special interest, since this endpoint is a direct measure of DNA damage and genomic instability and extensive literature is available on this assay as a biomarker of exposure and cancer risk.

While the group of formerly exposed workers showed a consistent increase of DNA damage in comparison with unexposed controls (accompanied by the higher CC and binucleated cell frequency), the group of workers which were classified as currently exposed to asbestos showed remarkably lower frequency ratios with respect to unexposed workers, especially as far as $\mathrm{MN}$ is concerned $(0.45,95 \% \mathrm{CI} 0.29-0.71)$, but also for broken eggs and basal cells.

Currently OEA workers were mostly selected from workers of the construction industry at high risk of asbestos contamination and undergoing regulatory health surveillance. Construction work in industrial or residential buildings is generally considered among the occupations with the highest OEA risk, even after the asbestos ban $(1,5)$. Although the current rigorous occupational surveillance concerning OEA limits the exposure to minimal levels, a reduction of DNA damage among these workers was unexpected. An ad hoc sensitivity analysis showed that the age difference was not responsible of this finding. Additional explanations may deal with the higher frequency of smokers in the current OEA group, the fact that MN frequency was lower in light smokers (26), or a possible healthy-worker effect due to the strong selection of individuals being hired for construction work.

On the contrary, the results referring to workers intensely exposed to asbestos in the past in several occupational settings were expected and consistent with a previous exposure to a carcinogenic agent. These workers are included in a cohort that is periodically monitored with the aim of preventing cancer development or to allow an early diagnosis of cancer.

The present research evaluated the information provided by all endpoints of the BMCyt. This multi-endpoints approach allowed for the measurement of early changes, including those that occur before genomic instability induces changes in cell cytokinesis. Cellproliferation is a measure of healthy buccal epithelium, since a constant rate of cell division allows to maintain a balance between exfoliating epithelial cells and their replacement (27). Lower basal cell frequency, as observed in the exposed groups, demonstrated the activation of apoptotic/necrotic pathway due to the presence of irreparable damage (28). However, since karyolitic cells frequency (necrotic pathway) in our exposed subjects was not affected, we can assume that necrotic pathway mechanisms were not involved, with the implication that OEA may impact only on differentiation and maturation of epithelium development $(19,29)$. The presence of cells with extensive DNA damage directed to the apoptotic pathway is revealed by the number of $\mathrm{CC}$, karryorrhectic or pycnotic cells. In our case, the only cell type with a higher frequency in exposed groups was CC in formerly exposed, possibly because of an early apoptotic event due to rapid proteolysis of nuclear matrix proteins (20).

The most remarkable result of the study is the increased MN frequency observed in the group of formerly exposed workers, which can be associated with increased risks of cancer and other degenerative diseases and, in addition, seems to be a promising marker in prescreening and follow up of precancerous oral lesions $(30,31)$.

The potential impact of lifestyle on genomic damage was carefully evaluated in our study to remove possible biases due to an unbalanced distribution of potential confounders, especially age, which may also imply very different exposures to genotoxic agents. Smoking and alcohol consumption had a limited influence on the level of DNA damage and proliferation, as estimated by multiple regression modelling. This result is not surprising since the literature is divided on the effect of smoking $(26,32,33)$ and only heavy smokers show a clear effect. The high prevalence of light smokers in our study groups ( $75 \%$ of smokers consumed $<20$ cigarettes/day) may account for this lack of association (33). As regards the effect of diet, it has been repeatedly shown that some dietary components, especially antioxidants, can influence MN frequency in buccal cells and may stimulate a reversal of the carcinogenic processes in oral cancers (34-37). No specific dietary item significantly affected the frequency of DNA damage in our study, however, lower levels of DNA damage were observed among subjects with the highest consumption of fresh fruit and vegetables and those taking vitamin supplements.

The results observed for the MN frequency in the currently exposed groups suggests that these workers have a lower genomic damage/disease risk when compared to the group of unexposed subjects. This result should be interpreted with caution, though it supports the conclusion that subjects now working in occupations that in the past determined heavy exposures to asbestos do not suffer any longer major genomic damage due to occupational exposure. On the other hand, the result concerning subjects exposed to (presumably) high lev- 
els of asbestos in the past, show that a higher genomic instability can be still recognized, and the consequent higher risk of asbestos-related cancers monitored and contrasted. These results support the use of the buccal MN cytome assay for the early detection of susceptible subgroups or individuals in groups of OEA workers as well as its use as a valuable tool for the monitoring of cohort of subjects with past exposures to carcinogenic agents (other examples are cohorts of subjects exposed to ionizing radiation, ex-smokers, recovering alcoholics, etc.). The other endpoints of the assay provide valuable information, although more research should be done before they can be validated for similar purposes (12).

The choice of a multi-endpoint study design may endorse the sensitivity of the investigation, as confirmed by a recent study conducted on these same subjects using biomarkers of oxidative damage such as the 3-(2-deoxy$\beta$-D-erythro-pentafuranosyl) pyrimido[1,2- $\alpha]$ purin$10(3 \mathrm{H})$-one deoxyguanosine adduct, which revealed a similar pattern of DNA damage in OEA workers and whose results reinforce the present evidence (38).

\section{Strengths and limitations}

This study has a number of strengths, including the availability of a large cohort of subjects with past exposure to carcinogens, a condition which represents a public health priority, and the use of a surrogate tissue that proved to be very sensitive for monitoring inhalatory exposures. Other pros are the extensive set of confounders evaluated, the use of standardized methods with a single scorer to reduce technical heterogeneity, and - for the first time - the evaluation of all endpoints from the BMCyt. This study also had some limitations, and the most critical being the lack of a direct assessment of individual and cumulative dose. However, OEA was evaluated through validated questionnaires, and the presence or exclusion of asbestos exposure was done by expert assessors with extensive experience on OEA classification [MN and DU]. Another limitation was the use of the exposure duration to surrogate cumulated dose.

In conclusion, applying the BMCyt to workers potentially exposed to asbestos may contribute to identify populations with an increased genomic instability. which in turn implies a higher risk of cancer and other chronic diseases. MN frequency should be used in combination with complementary biomarkers. The same approach can also be used in groups of subjects included in medical surveillance programs because of past exposure to carcinogens. In this case the biomarkers may identify subgroups at higher risk, which require a more intense observation, or can be further studied for a possible individual risk assessment. The use of other endpoints of the cytome assay may provide valuable support for the interpretation of $\mathrm{MN}$ results, although their use is to be mostly intended as explorative and should be to be further evaluated.

\section{Funding}

Funding support was provided through research grants from the Istituto Nazionale Assicurazione Infortuni sul Lavoro (INAIL), the Associazione Italiana per la Ricerca sul Cancro (AIRC), the $5 \times 10002013$ grant from the Italian Ministry of Health and the University of Genoa. None of the authors received financial or material support from organizations with a direct financial interest in the production or marketing of asbestos products.

\section{References}

1. IARC Working Group on the Evaluation of Carcinogenic Risk to Humans. Arsenic, Metals, Fibres and Dusts. Lyon (FR): International Agency for Research on Cancer; 2012. (IARC Monographs on the Evaluation of Carcinogenic Risks to Humans, No. 100C.) Asbestos (Chrysotile, Amosite, Crocidolite, Tremolite, Actinolite and Anthophyllite) Available from: https://www.ncbi.nlm.nih.gov/books/NBK304374/, [accessed 18th February 2017]

2. Carbone M, Kratzke RA, Testa JR. The pathogenesis of mesothelioma. Semin Oncol 2002 Feb;29(1):2-17. http:// dx.doi.org/10.1053/sonc.2002.30227.

3. Corfiati M, Scarselli A, Binazzi A, Di Marzio D, Verardo M, Mirabelli D et al.; ReNaM Working Group. Epidemiological patterns of asbestos exposure and spatial clusters of incident cases of malignant mesothelioma from the Italian national registry. BMC Cancer 2015 Apr;15(1):286. http://dx.doi. org/10.1186/s12885-015-1301-2.

4. INAIL. Registro Nazionale dei Mesoteliomi, Quinto rapporto, INAIL, Roma, 2015. Available from: https://www.inail.it/ cs/internet/docs/ucm_207055.pdf. [accessed 18th February 2017]

5. Marinaccio A, Binazzi A, Marzio DD, Scarselli A, Verardo M, Mirabelli D et al.; ReNaM Working Group. Pleural malignant mesothelioma epidemic: incidence, modalities of asbestos exposure and occupations involved from the Italian National Register. Int J Cancer 2012 May;130(9):2146-54. http://dx.doi.org/10.1002/ijc.26229.

6. Shukla A, Gulumian M, Hei TK, Kamp D, Rahman Q, Mossman BT. Multiple roles of oxidants in the pathogenesis of asbestos-induced diseases. Free Radic Biol Med 2003 May;34(9):1117-29. http://dx.doi.org/10.1016/S08915849(03)00060-1.

7. Dostert C, Pétrilli V, Van Bruggen R, Steele C, Mossman BT, Tschopp J. Innate immune activation through Nalp3 inflammasome sensing of asbestos and silica. Science 2008 May;320(5876):674-7. http://dx.doi.org/10.1126/ science. 1156995 .

8. Grivennikov SI, Greten FR, Karin M. Immunity, inflammation, 
and cancer [Review]. Cell 2010 Mar;140(6):883-99. http:// dx.doi.org/10.1016/j.cell.2010.01.025.

9. Neri M, Ugolini D, Boccia S, Canessa PA, Cesario A, Leoncini $\mathrm{G}$ et al. Chemoprevention of asbestos-linked cancers: a systematic review. Anticancer Res 2012 Mar;32(3):1005-13.

10. Cortez BA, Quassollo G, Caceres A, Machado-Santelli GM. The fate of chrysotile-induced multipolar mitosis and aneuploid population in cultured lung cancer cells. PLoS One 2011 Apr;6(4):e18600. http://dx.doi.org/10.1371/ journal.pone.0018600.

11. Proia NK, Paszkiewicz GM, Nasca MA, Franke GE, Pauly JL. Smoking and smokeless tobacco-associated human buccal cell mutations and their association with oral cancer--a review. Cancer Epidemiol Biomarkers Prev 2006 Jun;15(6):1061-77. http://dx.doi.org/10.1158/1055-9965. EPI-05-0983.

12. Bonassi S, Milić M, Neri M. Frequency of micronuclei and other biomarkers of DNA damage in populations exposed to dusts, asbestos and other fibers. A systematic review. Mutat Res Rev. 2016;770(Pt A):106-18.

13. Cortez BA, Rezende-Teixeira P, Redick S, Doxsey S, Machado-Santelli GM. Multipolar mitosis and aneuploidy after chrysotile treatment: a consequence of abscission failure and cytokinesis regression. Oncotarget 2016 Feb;7(8):897992. http://dx.doi.org/10.18632/oncotarget.6924.

14. Fenech M, Kirsch-Volders M, Natarajan AT, Surralles J, Crott JW, Parry J et al. Molecular mechanisms of micronucleus, nucleoplasmic bridge and nuclear bud formation in mammalian and human cells. Mutagenesis 2011 Jan;26(1):125-32. http://dx.doi.org/10.1093/mutage/ geq052.

15. Kamp DW, Weitzman SA. The molecular basis of asbestos induced lung injury. Thorax $1999 \mathrm{Jul} ; 54(7): 638-52$. http:// dx.doi.org/10.1136/thx.54.7.638.

16. Ceppi M, Munnia A, Cellai F, Bruzzone M, Peluso ME. Linking the generation of DNA adducts to lung cancer. Toxicology 2017 Sep;390:160-6. http://dx.doi. org/10.1016/j.tox.2017.09.011.

17. Bonassi S, Znaor A, Ceppi M, Lando C, Chang WP, Holland $\mathrm{N}$ et al. An increased micronucleus frequency in peripheral blood lymphocytes predicts the risk of cancer in humans. Carcinogenesis 2006 Mar;28(3):625-31. http://dx.doi. org/10.1093/carcin/bgl177.

18. Gennaro V, Ugolini D, Viarengo P, Benfatto L, Bianchelli M, Lazzarotto A et al. Incidence of pleural mesothelioma in Liguria Region, Italy (1996-2002). Eur J Cancer 2005 Nov;41(17):2709-14. http://dx.doi.org/10.1016/j. ejca.2005.04.047.

19. Thomas P, Holland N, Bolognesi C, Kirsch-Volders M, Bonassi S, Zeiger E et al. Buccal micronucleus cytome assay. Nat Protoc 2009;4(6):825-37. http://dx.doi. org/10.1038/nprot.2009.53.

20. León-Mejía G, Quintana M, Debastiani R, Dias J, EspitiaPérez L, Hartmann A et al. Genetic damage in coal miners evaluated by buccal micronucleus cytome assay. Ecotoxicol Environ Saf 2014 Sep;107:133-9. http://dx.doi. org/10.1016/j.ecoenv.2014.05.023.

21. Holland N, Bolognesi C, Kirsch-Volders M, Bonassi S, Zeiger E, Knasmueller $\mathrm{S}$ et al. The micronucleus assay in human buccal cells as a tool for biomonitoring DNA damage: the HUMN project perspective on current status and knowledge gaps. Mutat Res 2008 Jul-Aug;659(1-2):93-108. http://dx.doi.org/10.1016/j.mrrev.2008.03.007.

22. Bonassi S, Coskun E, Ceppi M, Lando C, Bolognesi C, Burgaz $\mathrm{S}$ et al. The HUman MicroNucleus project on eXfoLiated buccal cells (HUMN(XL)): the role of life-style, host factors, occupational exposures, health status, and assay protocol. Mutat Res 2011 Nov-Dec;728(3):88-97. http:// dx.doi.org/10.1016/j.mrrev.2011.06.005.

23. Ceppi M, Biasotti B, Fenech M, Bonassi S. Human population studies with the exfoliated buccal micronucleus assay: statistical and epidemiological issues. Mutat Res 2010 Jul-Sep;705(1):11-9. http://dx.doi.org/10.1016/j. mrrev.2009.11.001.

24. Cameron AC, Trivedi PK. Regression Analysis of Count Data. 1st ed. New York: Cambridge University Press. 1988.

25. Dhillon VS, Thomas P, Fenech M. Comparison of DNA damage and repair following radiation challenge in buccal cells and lymphocytes using single-cell gel electrophoresis. Int J Radiat Biol 2004 Jul;80(7):517-28. http://dx.doi.org/1 $0.1080 / 09553000410001723866$.

26. Bonassi S, Neri M, Lando C, Ceppi M, Lin YP, Chang WP et al.; HUMN collaborative group. Effect of smoking habit on the frequency of micronuclei in human lymphocytes: results from the Human MicroNucleus project. Mutat Res 2003 Mar;543(2):155-66. http://dx.doi.org/10.1016/S13835742(03)00013-9.

27. Torres-Bugarín O, Zavala-Cerna MG, Nava A, FloresGarcía A, Ramos-Ibarra ML. Potential uses, limitations, and basic procedures of micronuclei and nuclear abnormalities in buccal cells [Review]. Dis Markers 2014;2014:956835. http://dx.doi.org/10.1155/2014/956835.

28. de Aquino T, Zenkner FF, Ellwanger JH, Prá D, Rieger A. DNA damage and cytotoxicity in pathology laboratory technicians exposed to organic solvents. An Acad Bras Cienc 2016 Mar;88(1):227-36. http://dx.doi.org/10.1590/00013765201620150194 .

29. Cerqueira EM, Gomes-Filho IS, Trindade S, Lopes MA, Passos JS, Machado-Santelli GM. Genetic damage in exfoliated cells from oral mucosa of individuals exposed to X-rays during panoramic dental radiographies. Mutat Res 2004 Aug;562(1-2):111-7. http://dx.doi.org/10.1016/j. mrgentox.2004.05.008.

30. Bolognesi C, Bonassi S, Knasmueller S, Fenech M, Bruzzone $\mathrm{M}$, Lando $\mathrm{C}$ et al. Clinical application of micronucleus test in exfoliated buccal cells: A systematic review and metanalysis. Mutat Res Rev Mutat Res 2015 Oct-Dec;766:20-31. http://dx.doi.org/10.1016/j. mrrev.2015.07.002. 
31. Benner SE, Lippman SM, Wargovich MJ, Lee JJ, Velasco M, Martin JW et al. Micronuclei, a biomarker for chemoprevention trials: results of a randomized study in oral pre-malignancy. Int J Cancer 1994 Nov;59(4):457-9. http:// dx.doi.org/10.1002/ijc.2910590403.

32. Haveric A, Haveric S, Ibrulj S. Micronuclei frequencies in peripheral blood and buccal exfoliated cells of young smokers and non-smokers. Toxicol Mech Methods 2010 Jun;20(5):260-6. http://dx.doi.org/10.3109/15376516.2010 .482962 .

33. Nersesyan A, Muradyan R, Kundi M, Knasmueller S. Impact of smoking on the frequencies of micronuclei and other nuclear abnormalities in exfoliated oral cells: a comparative study with different cigarette types. Mutagenesis 2011 Mar;26(2):295-301. http://dx.doi.org/10.1093/mutage/ geq092.

34. Stich HF, Rosin MP. Micronuclei in exfoliated human cells as a tool for studies in cancer risk and cancer intervention. Cancer Lett 1984 Apr;22(3):241-53. http://dx.doi. org/10.1016/0304-3835(84)90159-9.
35. Prasad MP, Mukundan MA, Krishnaswamy K. Micronuclei and carcinogen DNA adducts as intermediate end points in nutrient intervention trial of precancerous lesions in the oral cavity. Eur J Cancer B Oral Oncol 1995 May;31(3):155-9. http://dx.doi.org/10.1016/0964-1955(95)00013-8.

36. Hastak K, Lubri N, Jakhi SD, More C, John A, Ghaisas $\mathrm{SD}$ et al. Effect of turmeric oil and turmeric oleoresin on cytogenetic damage in patients suffering from oral submucous fibrosis. Cancer Lett 1997 Jun;116(2):265-9. http://dx.doi.org/10.1016/S0304-3835(97)00205-X.

37. Li N, Sun Z, Han C, Chen J. The chemopreventive effects of tea on human oral precancerous mucosa lesions. Proc Soc Exp Biol Med 1999 Apr;220(4):218-24. http://dx.doi. org/10.3181/00379727-220-44369.

38. Bonassi S, Cellai F, Munnia A, Ugolini D, Cristaudo A, Neri $M$ et al. 3-(2-deoxy- $\beta$-d-erythro-pentafuranosyl) pyrimido[ $[1,2-\alpha]$ purin-10(3H)-one deoxyguanosine adducts of workers exposed to asbestos fibers. Toxicol Lett 2017 Mar;270:1-7. http://dx.doi.org/10.1016/j. toxlet.2017.02.008.

Received for publication: 4 August 2017 